\title{
PENGARUH FAKTOR SOSIAL PADA KEPUASAN HIDUP DALAM LINGKUNGAN TENAGA AKADEMIK PERGURUAN TINGGI
}

\author{
Yoyok Soesatyo \\ yoyoksoesatyo3@gmail.com \\ Pendidikan Ekonomi, Universitas Negeri Surabaya
}

\begin{abstract}
There are problems of life satisfaction in the academic personnel of public universities in East Java. Therefore, this study aims to determine the management of social factors, namely social capital, social capital benefits and human capital to the life satisfaction of academic personal.And to test the conceptual model of the research. Methods used to obtain data Cronbach's Alpha and the search result was around 0,6654-0,8854. Collected data was analyzed using Structural Equation Modeling (SEM) to test the problems, test the objective and test the hypothesis. This result indicate that (a) the three factors of social capital (social capital benefit, human capital) have significant impact on life satisfaction. Minimum rate score above 3 to near 5. (b) Social capital and life satisfaction have significant correlation 0,037 of star sign. (c) Social capital and social capital benefit have no significant correlation 0,065. (d) Social capital and human capital have significant correlation 0,040. (e) Social capital benefit and life satisfaction have significant correlation 0,045. (f) Human capital and life satisfaction have significant correlation 0,042 and to fulfilled at least 2 criterias good fit measure: Probability, RMSEA and TLI.
\end{abstract}

Keywords : life satisfaction, social factor, social capital benefit.

\begin{abstract}
ABSTRAK
Terdapat permasalahan kepuasan hidup tenaga akademik dilingkungan perguruan tinggi negeri Jawa Timur. Penelitian ini bertujuan untuk mengetahui pengelolaan faktor sosial yaitu modal sosial, manfaat modal sosial, dan modal manusia terhadap kepuasan hidup tenaga akademik. Serta menguji model konseptual penelitian. Metode yang digunakan adalah Cronbach's Alpha dan hasil pengolahan menunjukkan nilai Cronbach's Alpha 0,6654-0,8854. Analisis menggunakan rumus Structural Equation Modeling (SEM) untuk menguji rumusan masalah dan hipotesis penelitian. Hasil penelitian menunjukkan; (a) ketiga faktor dalam variabel modal sosial, manfaat modal sosial, modal manusia dan kepuasan hidup mempunyai pengaruh yang signifikan. Secara keseluruhannya nilai min skor melebihi nilai skor 3 dan ada yang mendekati nilai skor 5 (b) modal sosial dengan kepuasan hidup mempunyai nilai signifikasi 0,037. (c) modal sosial dengan manfaat modal sosial tidak terdapat pengaruh karena memiliki nilai signifikasi 0,065 (d) modal sosial dengan modal manusia mempunyai nilai signifikasi 0,040 . (e) manfaat modal sosial dengan kepuasan hidup mempunyai pengaruh dengan nilai signifikasi 0,045 (f) modal manusia dengan kepuasan hidup mempunyai pengaruh dengan nilai signifikasi 0,042 dan hasil interpretasi Full model, menunjukkan bahwa model konseptual penelitian dapat dipertahankan karena sekurang-kurangnya terdapat 2 kriteria fit measure yaitu Probabilitas, RMSEA dan TLI dipenuhi dengan baik.
\end{abstract}

Kata kunci: kepuasan hidup, faktor sosial, manfaat modal sosial.

\section{PENDAHULUAN}

Kepuasan hidup seseorang dapat diukur dari berbagai faktor antara lain faktor sosial, walaupun pada dasarnya setiap orang memiliki ukuran yang berbeda-beda. Namun demikian atas dasar teori dan hasil penelitian terdahulu dapat digunakan sebagai acuan/rujukan untuk melakukan suatu penelitian.

Kepuasan hidup merupakan tujuan utama setiap orang, oleh karena itu setiap orang akan berusaha secara maksimal untuk 
meningkatkan kehidupan mereka sebaikbaiknya secara pribadi maupun secara kelompok. Kepuasan hidup setiap orang dipengaruhi oleh berbagai faktor sosial yang berhubungan dengan upaya mereka melakukan berbagai kegiatan untuk memenuhi kebutuhan hidup yang diinginkan, status sosial ekonomi, dan fasilitas sosial dalam menunjang kegiatan mereka untuk melakukan tugas dan kewajibannya. Tenaga akademik dalam melakukan kegiatan tersebut perlu memperhatikan berbagai aspek yang dapat mempengaruhi tercapainya kepuasan hidup.

Kepuasan hidup dalam penelitian ini menghubungkan dengan faktor sosial antara lain faktor modal sosial meliputi dimensi struktural, kognitif, dan relasional. Faktor manfaat modal sosial meliputi akses informasi, fasilitas, dan sponsor kinerja. Faktor modal manusia meliputi kompetensi pedagogik, kepribadian, sosial, dan profesional yang mereka miliki (Robbins, 2003). Faktor sosial akan bermakna bagi seseorang, kelompok dan kelembagaan bilamana dikelola secara benar, tepat dan sesuai dengan etika, moral, budaya organisasi serta peraturan/ perundang-undangan yang berlaku.

Kepuasan hidup tenaga akademik perguruan tinggi negeri di Jawa Timur, berdasarkan hasil observasi awal dan pengamatan di lapangan menunjukkan adanya berbagai persoalan/fenomena yang terjadi baik secara individual, kelompok maupun dari sisi kelembagaan, sedangkan faktor sosial yang dapat menimbulkan persoalan adalah karena keterbatasan yang bersifat kompleks, dilingkungan perguruan tinggi tidak mampu mengikuti perkembangan budaya, iptek dan kebutuhan yang berkembang lebih cepat dari pada kemampuan yang dimiliki oleh perguruan tinggi. Faktor sosial yang dapat menimbulkan persoalan antara lain; gaji yang diterima tidak cukup untuk biaya hidup, keterbatasan dana dan fasilitas kerja yang tersedia antara lain; motivasi dan bantuan mengikuti seminar/ workshop/pelatihan, bantuan study lanjut, laboratorium, perpustakaan, beban tugas yang melebihi ketentuan yang berlaku, peluang melakukan penelitian dan pengabdian kepada masyarakat, kenaikan jabatan fungsional, kesehatan, perumahan transportasi, sehingga tenaga akademik untuk melaksanakan tugas dan kewajiban Tri Dharma Perguruan Tinggi mengalami hambatan dan permasalahan.

Modal sosial (social capital) yang dimiliki setiap orang berbeda walaupun dilahirkan pada waktu, bulan dan tahun yang sama. Keadaan ini sangat dipengaruhi oleh kedudukan sosial yang ada disekelilingnya. Modal sosial telah dibicarakan pada tahun 1916 untuk membangun pusat pembelajaran masyarakat (Robbins, 2003). Fukuyama (2000), telah menulis dua buah buku mengenai modal sosial yaitu Trust: "The social virtues and the creation of Prosperty" yang diterbitkan pada tahun 1995, dan The Great Depression: Human Nature and the Reconstitution of Social Order yang diterbitkan pada tahun 2000. Fukuyama (2000), menyatakan bahwa jaringan sosial dapat digunakan untuk mencapai keberhasilan suatu tujuan. Selain itu Fukuyama telah menjadikan konsep modal sosial semakin populer. Ini juga banyak dibicarakan dalam artikel mengenai topik tersebut dari berbagai prespektif, namun, penulisan mengenai modal sosial dari aspek manajemen sumberdaya manusia belum banyak dihasilkan khususnya dalam penelitian.

Marshall (2005), menyatakan bahwa human capital yang terdiri dari pendidikan, kesehatan, dan motivasi merupakan faktor penting/penentu bagi pengembangan seseorang. Segall et al., (2010), menyatakan bahwa human capital terdiri dari tingkat pendidikan formal dan pengalaman yang diperoleh sebelumnya.

Beberapa hasil penelitian yang mendukung penelitian ini ialah, Siebert et al., (2001), mengintegrasikan konsep modal sosial dan kepuasaan hidup dan keberhasilan kinerja. Hasil penelitian menunjukkan bahwa modal sosial berpengaruh terhadap kepuasan hidup dan keberhasilan kinerja. Secara spesifik yang berpengaruh 
dengan tahap modal sosial diukur sebagai jumlah konteks pengembangan dalam kumpulan fungsi lain dalam organisasi (contacts in other functions) dan tahap yang lebih tinggi dalam organisasi (contacts at higher levels), modal sosial berpengaruh positif dengan gaji yang diterima, jumlah kenaikan pangkat yang diterima selama bekerja (promotion, entire career), dan kepuasan hidup atau kinerja (career satistaction) berhubung positif dengan akses informasi (access to information), akses fasilitas (access to resourses) dan sponsor kinerja (career sponsorship). Populasi dan sampel penelitian diambil dari lulusan Sarjana perniagaan, teknik dan program Master Bussines Administration (MBA).

Hsu et al., (2003), melakukan penelitian tentang pengaruh tingkat kinerja (career stage) dan bidang kinerja (career anchor) ter hadap kepuasan kinerja (career satisfaction) sistem informasi professional (IS) di manabidang kinerja dibatasi dari segi teknik dan manajemen. Hasil penelitian dengan analisis regresi menunjukkan adanya pengaruh positif dan signifikan antara tingkat kinerja terhadap kepuasan kinerja, dan ahli akademik yang berada pada tingkat kinerja yang didukung oleh organisasi mempunyai tingkat kepuasan kinerja yang lebih tinggi dari tingkat kinerja yang menggunakan mentor. Selanjutnya, analisis kinerja secara terpisah dilakukan untuk mengetahui apakah ada pengaruh yang berbeda menurut tingkat kinerjanya, dan hasilnya menunjukkan bahwa pada tingkat kinerja yang mentor mempunyai pengaruh positif dan signifikan mengikut bidang kinerja terhadap kepuasan kinerja, sedangkan, pada tingkat kinerja yang didukung oleh organisasi menunjukkan pengaruh yang tidak signifikan.

Tenaga akademik perguruan tinggi merupakan sumber tenaga manusia terpenting dalam upaya menyiapkan tenaga kerja yang profesional, memiliki karakter, cinta tanah air dan nusa bangsa, berjiwa patriotisme dan nasionalisme, jujur dan mampu sebagai teladan, membentuk pribadi mahasiswa yang selalu mengikuti perkembangan bu- daya, Iptek dan Imtaq. Oleh sebab itu sangat wajar dan manusiawi bilamana tenaga akademik dikelola dan diatur secara bijak, agar mampu melaksanakan semua tugas dan kewajiban sesuai ketentuan yang berlaku dan tidak banyak menimbulkan masalah serta dapat memberikan kepuasan hidupnya.

Keberhasilan sebuah perguruan tinggi antara lain diukur berdasarkan latar belakang akademik, jabatan fungsional dan karya ilmiah yang dihasilkan oleh tenaga akademik. (Undang undang nomor 20 tahun 2003). Perguruan tinggi yang status akreditasinya bagus atau memperoleh nilai $\mathrm{A}$ adalah perguruan tinggi yang mampu memberikan fasilitas, motivasi, dorongan, dan dukungan kepada civitas akademika sehingga terbentuk situasi akademik yang mampu membangun kampus yang selalu mengikuti perkembangan Iptek dan Imtaq. Peranan tenaga akademik sangat dominan dalam upaya membangun situasi kampus yang mampu menyiapkan tenaga kerja profesional dan bersaing di pasar kerja serta membuka lapangan kerja baru. Hasil penelitian Gattiker dan Larwood (1998), tentang kepuasan kinerja meliputi kepuasan hidup berkaitan langsung dengan kondisi dan hasil kerja/prestasi suatu organisasi, hasil penelitian dapat dirumuskan bahwa keberhasilan sebuah perguruan tinggi adalah berhubungan erat dengan kepuasan hidup.

Dari fenomena tersebut di atas, dapat dirumuskan: (1) adakah pengaruh modal sosial sebagai variabel bebas dengan kepuasan hidup sebagai variabel terikat; (2) adakah pengaruh modal sosial sebagai variabel bebas dan kepuasan hidup sebagai variabel terikat dengan manfaat modal sosial sebagai variabel mediator; (3) adakah pengaruh modal sosial sebagai variabel bebas dan kepuasan hidup sebagai variabel terikat dengan modal manusia sebagai variabel mediator.

Berdasarkan fenomena yang terjadi dilingkungan perguruan tinggi, merujuk beberapa teori dan hasil penelitian terdahulu 
yang relevan serta berbagai pendapat para ahli, maka peneliti mencoba membuat ben tuk "Model Konseptual Penelitian" semen tara seperti pada gambar1.

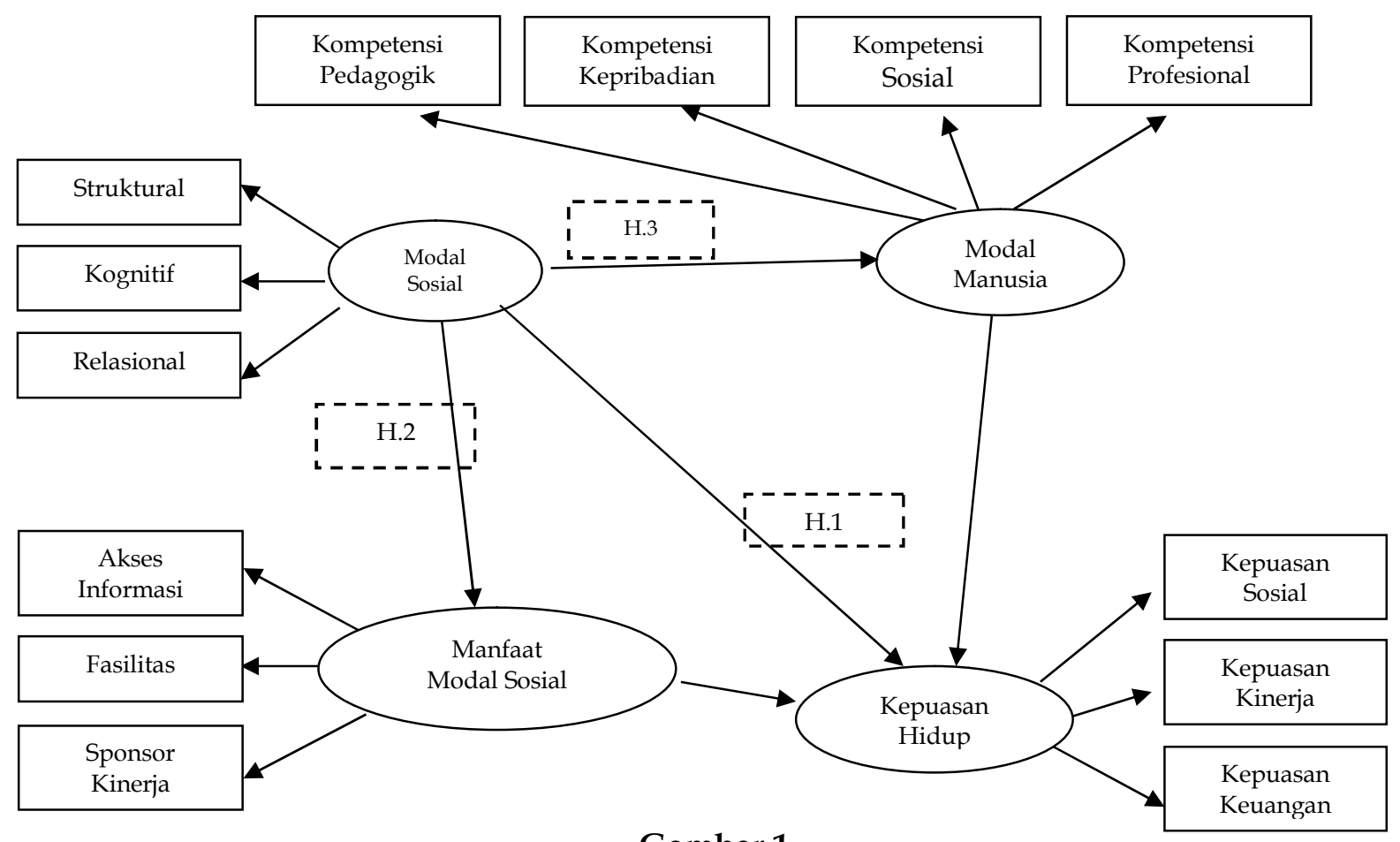

Gambar 1

Sumber : Konsep peneliti yang akan diujikan melalui analisis SEM

Dasar teori yang digunakan dalam pembuatan Model Konseptual Penelitian di atas antara lain: Pertama, Melalui modal dalam membangun jaringan baik perilaku secara pribadi maupun kelompok/organisasi dapat memperbesar modal sosial mereka sehingga mendapat manfaat dalam bentuk jaringan yang tinggi terhadap informasi, kekuatan dan solidaritas (Seibert et al, 2001). Kedua, manfaat jaringan tentang akses informasi, fasilitas dan sponsor kinerja dan penggunaan mentor mempunyai pengaruh yang positif terhadap kepuasan suatu kinerja subjektif maupun secara objektif (Fukuyama, 2000). Ketiga, modal manusia/Human capital merupakan intangible aset yang dimiliki sebagai kekuatan lebih besar dibandingkan dengan tangible aset dan juga didasarkan sebagai keberhasilan lembaga. Modal manusia dipandang sebagai elemen strategik karena kinerja dan pengelolaan sumber daya manusia memberikan andil yang besar untuk menciptakan keunggulan bersaing (Ongkoraharjo, 2008). Keempat, kepuasan hidup dapat terwujud bilamana keperluan hidup sudah terpenuhi dan terkait dengan tingkat kepuasan yang diinginkan dan yang diperoleh/dicapai setelah memberikan pengorbanan (Robbins, 2003).

Berdasarkan permasalahan di atas, tujuan penelitian ini menganalisis tentang pengaruh modal sosial (variabel bebas), manfaat modal sosial dan modal manusia (variabel mediator) terhadap kepuasaan hidup tenaga akademik perguruan tinggi negeri di Jawa Timur (variabel terikat). Dan menguji model konseptual penelitian yang diusulkan dalam diagram alur (model teoritis) sesuai (fit) dengan data hasil penelitian yang diperoleh dari responden dapat diterima atau ditolak.

\section{TINJAUAN TEORETIS}

Kajian teori yang digunakan berdasarkan pada definisi dan konsep tentang modal sosial, manfaat modal sosial, modal manusia 
dan kepuasan hidup tenaga akademik diperguruan tinggi negeri Jawa Timur yang dikaji untuk menentukan pengaruh dari variabel penelitian ini dan mengemukakan perkembangan terhadap penelitian-penelitian empirikal serta hasil penelitian yang dilakukan terdahulu sesuai dengan judul penelitian ini.

Menurut Coleman (1990) modal sosial dapat disesuaikan (appropriable) dan dapat diubah (convertible). Modal sosial dapat disesuaikan dalam pengertian bahwa jaringan ikatan persahabatan dari seseorang dapat digunakan untuk tujuan lain, seperti pengumpulan informasi dan saran. Selain itu, modal sosial dapat diubah kejenis modal lain yaitu manfaat ekonomi atau lainnya. Tingkat perubahan (convertibility rate) modal sosial lebih rendah dibandingkan dengan modal ekonomi, karena modal sosial tidak mudah berubah.

Modal sosial dapat menjadi pengganti ataupun dapat melengkapi sumber daya lainnya. Sebagai pengganti kadang-kadang dapat mengimbangi adanya modal keuangan atau modal manusia dalam kondisi yang sangat signifikan. Modal sosial memerlukan pemeliharaan secara berkala dan harus dilakukan pembaharuan agar lebih memiliki kekuatan. Modal sosial tidak mengalami tekanan yang dapat diramal karena dua alasan, yaitu: (1) sementara modal sosial dapat mengalami tekanan karena penyalahgunaan, biasanya tumbuh dan berkembang karena sering dimanfaatkan; (2) modal sosial menjadi tidak berguna karena perubahan kontekstual, hal ini terjadi oleh kejadian yang tidak dapat diramalkan karena prinsip perhitungan yang konservatif tidak dapat mendeteksi.

Modal sosial bersifat kolektif dan bukan merupakan milik pribadi bagi setiap orang yang mengambil manfaat darinya. Khususnya modal sosial seperti ini bersifat nonrival, penggunaan dari seseorang tidak akan mengurangkan availability bagi orang lain tetapi penggunaannya dapat ditiadakan, orang lain dapat dikeluarkan dari jaringan tersebut. Perwatakan tersebut membuat modal sosial mudah terkena permasalahan free rider dan timbulnya resiko tragedi dari keadaan yang biasa. Modal sosial disebut modal karena penanaman modal sosial dalam perkembangannya dapat diperlihatkan dengan cara pengukurannya.

Modal sosial adalah jumlah sumber daya aktual dan potensial yang terdapat di dalamnya, tersedia ada melalui hubungan dan jaringan yang dimiliki oleh suatu kesatuan individu atau sosial. Manfaat modal sosial meliputi: 1) akses informasi yang lebih luas dan meningkatkan kualitas informasi, relevansi dan timeliness; 2) manfaat kekuasaan, ini dapat memiliki externality positif bagi seseorang dan ikatan organisasi yang lebih luas; 3) kesamaan norma-norma dan keyakinan sosial yang kuat, mendorong untuk mematuhi terhadap peraturan dan kebiasaan serta mengurangi kesalahan yang bersifat formal.

Semua jaringan saluran dapat memberikan fleksibiliti yang besar untuk membentuk struktur jaringan informal secara optimal dan juga memberikan sebagian besar struktur yang efektif. Hal ini didukung dengan hasil penelitian yang menunjukkan bahwa anggota masyarakat tidak selalu menerima informasi melalui media massa, melainkan lebih mudah menerima melalui jaringan sosialnya atau dengan kata lain mereka menerima informasi dari media massa, namun informasi tersebut lebih diperkuat dari jaringan sosial. Komunikasi bukan sekedar suatu rangkaian kegiatan dan pertukaran informasi, tetapi lebih merupakan suatu pertukaran informasi antara dua orang atau lebih yang berdasarkan informasi sebelumnya dan bermanfaat bagi kedua belah pihak untuk mencapai suatu pemahaman dan menuju arah yang sama.

Merujuk beberapa hasil penelitian terdahulu terdapat pengertian tentang manfaat modal sosial dan resiko, menyatakan bahwa ada tiga alasan yang dapat digunakan untuk menjustifikasi pandangan yang lebih profesional antara manfaat (benefits) dan risiko (risks) dari modal sosial. Dalam konteks manfaat modal sosial sebagai variabel dapat diperhatikan dari tiga dimensi yaitu akses informasi, fasilitas, dan sponsor kinerja (Sibert, 2001). Gargiulo \& Bernassi (1999) menyatakan bahwa manfaat modal sosial 
dan resiko terdiri dari tiga alasan yang dapat digunakan menjustifikasi pandangan yang lebih profesional antara manfaat (benefits) dan resiko (risks) dari modal sosial.

Modal manusia dapat diartikan sebagai manusia yang secara personal bekerja di lingkungan perguruan tinggi dengan modal kemampuan, komitmen, pengetahuan dan pengalaman pribadi yang dimiliki. Modal manusia sebagai gabungan dari tiga faktor yaitu; (1) watak/sifat yang dibawa ke pekerjaan, contohnya; intelligence, tenaga, sikap positif, keunggulan dan komitmen; (2) kemampuan seseorang untuk belajar yaitu; kecerdasan, imaginasi, kreativitas dan bakat; dan (3) motivasi untuk berbagai informasi dan pengetahuan yaitu; semangat bekerja dan orientasi mencapai tujuan (Jae Fitz dan Enz, 2002). Kaitan modal manusia sebagai suatu variabel, meliputi; kompetensi pedagogik, kepribadian, sosial, dan profesional (Teirexia, 2002; Amstrong, 2007).

Menurut Amstrong (2007), bahwa individu mengadakan, menahan dengan menggunakan pengetahuan dan Skill (human capital) serta menciptakan modal intelektual. Pengetahuan mereka ditingkatkan dengan cara interaksi di antara mereka (social capital) dan mengembangkan kumpulan pengetahuan yang dimiliki oleh pertumbuhan-pertumbuhan (organization capital). Pengertian human capital adalah accumulation dari pada skill, pengetahuan, pengalaman, kreatifitas dan lain-lain yang berkaitan dengan pekerjaan.

Perguruan tinggi, terdiri dari individuindividu yang saling bekerjasama untuk mencapai tujuan. Organisasi tidak akan berjalan dengan baik tanpa adanya individu yang berkualitas dan saling bekerjasama. Manusia dengan segala kemampuan yang dimiliki merupakan komponen penting dalam organisasi perguruan tinggi, karena dapat mendorong dan mewujudkan keberhasilan perguruan tinggi dan menyiapkan para lulusan untuk masuk dunia kerja serta menghadapi persaingan yang bersifat global. Modal manusia dipandang sebagai elemen stategik organisasi, karena pengelolaan prestasi sumber daya manusia akan diikuti penyiapan dana yang besar untuk meng- hasilkan competitive advantage (Ongkoraharjo, 2008).

Portal (2008), menyatakan bahwa human capital merupakan intangible asset yang memiliki kekuatan lebih besar berbanding dengan tangible asset dan juga digunakan sebagai dasar terhadap kesuksesan organisasi. Disebutkan juga bahwa dibeberapa negara Eropa, Scandinavia dalam laporan tahunan sudah menyampaikan laporan intangible aset yang termasuk di dalamnya adalah human capital. Beberapa organisasi yang berdiri dan bertahan dalam persaingan bukan lagi disebabkan oleh tangible asset tetapi karena adanya intangible asset.

Boxall (1996), menyatakan bahwa human capital terdiri dari tingkat pendidikan, pengalaman dan skill. Jadi dalam pengertian human capital tidak hanya berbicara mengenai manusia saja, akan tetapi juga segala kemampuan dan apa yang dimiliki manusia tersebut sebagai makhluk yang bermanfaat untuk kepentingan orang lain. Schultz (1961), menyatakan sebagai berikut "consider all human abilities to be either or innate or acquired. Attribute, which are valuable and can be augmented by appropriate investment will be human capital". Bontis and Enz (2002), berpendapat human capital adalah faktor manusia dalam organisasi yang digabungkan dari intelegency skill dan kemahiran. Elemen manusia dalam organisasi yang mempunyai kemampuan belajar, berubah dan berinovasi.

Mayo (2000), menyebutkan bahwa human capital terdiri dari lima komponen yaitu individual capability, individual motivation, leadership, the organization climate, dan workgroup effectiviness, sedangkan Becker (1993), menyatakan bahwa tingkat pendidikan dapat membangunkan kemampuan akal pikiran dan pengetahuan untuk membuat strategi dalam organisasi guna menghadapi persaingan. Tingkat pendidikan adalah pendidikan formal sebelum melakukan pekerjaan di sebuah organisasi. Menurut Marshall (2005) human capital terdiri dari pendidikan, kesehatan dan motivasi yang merupakan penentu paling penting bagi seseorang dan perkembangan sosial. 
Bock (1982) dalam education and development: a conflict meaning menyatakan peranan pendidikan tersebut sebagai: (1) menginformasikan ideologi dan nilai-nilai sosial kebudayaan suatu bangsa, (2) menyediakan tenaga kerja untuk menghilangkan kemiskinan, kebodohan dan menggalakkan perubahan sosial, (3) untuk meningkatkan pendapatan. Pendidikan yang dimaksudkan baik melalui pendidikan formal maupun informal memberikan pengetahuan tentang perkembangan budaya, teknologi, etika, komunikasi, ilmu pengetahuan, sopan santun/budi pekerti, pengangkutan, perubahan sosial, agama, agar dapat menciptakan manusia yang mempunyai kemampuan dan ketrampilan dalam menghadapi permasalahan yang timbul dalam masyarakat.

Hasil kajian Triningsih (2007), menyimpulkan bahwa prestasi merupakan suatu hasil kerja yang dicapai seseorang dalam melaksanakan tugas yang diberikan kepadanya, yang didasarkan atas kecakapan, pengalaman dan kesungguhan yang diukur dengan hasil yang dicapai berdasarkan kualitas, kuantitas dan ketepatan waktu. Prestasi tersebut boleh diukur melalui ukuran tertentu dimana kualitas berkaitan dengan mutu kerja yang dihasilkan, sedangkan kuantitas adalah jumlah hasil prestasi yang dihasilkan dalam waktu tertentu, sedangkan ketepatan waktu adalah kesesuaian waktu yang telah ditetapkan.

Mayo (2000), pengalaman kerja yaitu seseorang yang berketetapan dan mempunyai pengalaman yang cukup lama dibidangnya serta memiliki sikap terbuka terhadap pengalaman. Pengalaman kerja akan meningkat sesuai dengan semakin meningkatnya complexity kerja. Schein and Diane (1972), menyatakan bahwa penyelidikan tentang kinerja dan kepuasan sesuatu kinerja harus ditempatkan dalam konteks kehidupan seseorang yang lebih besar (perspektif holistic). Determinan kepuasan sebuah kinerja secara subyektif, modal manusia yaitu nilai-nilai kerja, keluarga dan lingkungan pekerjaan.

Bretz dan Judge (1992), menyatakan bahwa hubungan antara kesesuaian orang dengan organisasi dan keberhasilan kinerja yang digambarkan dengan keberhasilan/ kepuasan intrinsic maupun ekstrinsic dipengaruhi secara signifikan oleh tingkat kesesuaian individu dalam organisasi. Rastogi (2002), menyatakan bahwa konsep dan perspektif dari human capital berasal dari kenyataan bahwa tidak ada pengganti untuk pengetahuan dan pembelajaran, kreatifitas dan inovasi, kompetensi dan kemampuan, dan mereka perlu terus menerus bekerja dan mengagendakan pada konteks lingkungan organisasi Organization for Economic Cooperation and Development (OECD) 2001.

Ongkoraharjo (2008) menyebutkan bahwa human capital sebagai pengetahuan, kemahiran, kompetensi yang merupakan atribut individu yang dapat digunakan untuk dirinya, sosial dan ekonomi. Kepuasan hidup terjadi apabila semua kebutuhan hidup seseorang dan apa yang diinginkan sudah terpenuhi berkaitan dengan tingkat kepuasan hidupnya, antara lain pengaruhnya dengan kepuasan sosial, kinerja, dan keuangan yang diperoleh sesuai dengan pengorbanan (Robbins, 2003). Kepuasan hidup meliputi; kepuasan sosial, kepuasan kinerja, dan kepuasan keuangan (Robbins, 2003).

Locke (1976), menyatakan bahwa kepuasan kerja disebabkan oleh pencapaian nilai-nilai yang seimbang dengan kehendak atau keinginan seseorang. Dari kedudukan atau nilai-nilai penting yang berguna bagi kepuasan kerja adalah: (1) secara mental menguasai pekerjaan dalam rangka mencapai kesuksesan; (2) minat pribadi dalam pekerjaan sendiri; (3) jangan bekerja secara fisik yang dapat melelahkan; (4) penghargaan atas kerja yang adil, bertujuan dan selaras dengan aspirasi pekerja; (5) kedudukan kerja adalah kompetitif dengan memerlukan fisik individu dan mudah memenuhi tujuan; (6) mengagumi diri sendiri terhadap hasil pekerjaan; (7) manajemen membantu pekerja untuk mencapai nilai-nilai pekerjaan antara lain pekerjaan yang menarik, gaji dan promosi, nilai-nilai dasar yang serupa dengan apa yang dimiliki dan pihak lain yang menghindari pertentangan dan ambiguous.

Baron dan Greenberg (1990), mengatakan bahwa kepuasan kerja dipengaruhi oleh tiga kategori, yaitu: (1) kebijakan dan 
budaya dalam organisasi; (2) keperluan dan kepentingan beberapa persoalan dalam suasana pekerjaan; (3) beberapa ciri latar belakang pekerjaan itu sendiri. Kebiasaan ketiga kategori tersebut menunjukkan kesan yang berlainan terhadap kepuasan kerja. Hackman dan Oldham (1976), menjelaskan bahwa kepuasan kerja itu dikaitkan dengan suasana kerja karena suasana kerja yang memberikan peluang kepada pekerja untuk berinteraksi antara satu sama yang lain, suasana kerja yang tidak mewujudkan pengasingan antara pekerja, lebih memberikan rasa kepuasan bekerja. Kategori penyebab yang dikembangkan oleh Oldham juga menyebutkan beberapa persoalan yang berhubungan dengan karakteristik pekerjaan, berbagai ketrampilan, identitas tugas, otonomi dan tanggungjawab.

Peningkatan kinerja merupakan upaya yang digunakan seseorang untuk memaksimalkan motivasi para pekerja. Motivasi merupakan sumber bagi kepuasan kerja, dan dengan motivasi akan menerima upah/pendapatan dan kemudahan meningkatkan jenjang karir. Sergiovanni (1987), menyatakan bahwa faktor fisik ditempat kerja tidak boleh diabaikan, karena merupakan penyebab kepuasan kerja. Ada empat faktor fisik yang dapat memberikan kepuasan kerja yaitu: (1) kepuasan sosial; (2) desain ruang kerja; (3) jarak antara tempat kerja dengan rekan kerja; (4) situasi dan kondisi ruang kerja, suasana sosial dilingkungan kerja yang dapat memberikan suasana kerjasama, dan semangat gotong royong sesama pekerja. Di lingkungan perguruan tinggi, tenaga akademik akan menyatakan bahwa mereka bekerja dalam suasana positif bilamana mempunyai kepuasan kerja yang tinggi.

Conley, Bacharach, dan Bauer (1989), menyatakan bahwa konsep tanggungjawab dan otonomi tenaga akademik yang ditentukan oleh struktur managemen akademik perguruan tinggi berhubungan dengan kepuasan kerja tenaga akademik. Bilamana hubungan tenaga akademik dan pimpinan lembaga terjadi konflik kerja, maka tenaga akademik mengalami kepuasan kerja yang rendah. Kepuasan hidup yang rendah juga berpangkal dari kurangnya kebebasan dan otonomi mengembangkan bakat kepemimpinan dan kemajuan diri mereka.

Kajian mengenai kepuasan hidup telah didominasikan oleh dua perspektif yaitu perspektif individualistik dan perspektif struktural. Pendekatan individualistik menyatakan bahwa aspirasi kinerja merupakan faktor utama untuk menentukan kinerja mereka termasuk mengetahui kekuatan dan kepentingan mereka, akan tetapi tidak berhubungan dengan sistem kinerja organisasi. Menurut Chapman dan Hutcheson (1982), menerangkan prinsip kepuasan kerja tenaga akademik dipengaruhi oleh empat persoalan, yaitu: (1) karakteristik dan latar belakang seseorang; (2) kopetensi yang dimiliki tenaga akademik; (3) persoalan yang penting sebagai dasar menilai kesuksesan kinerja; (4) penilaian dan pendapat dari orang lain.

Schemerhorn (2002), mengidentifikasi lima aspek yang terdapat dalam kepuasan kerja, yaitu: (1) pekerjaan itu sendiri (work it self), setiap pekerjaan memerlukan suatu ketrampilan tertentu. Sukar tidaknya suatu pekerjaan serta perasaan seseorang bahwa keahliannya diperlukan dalam melakukan pekerjaan tersebut akan meningkatkan atau mengurangi kepuasan kerja; (2) pembimbingan/supervisen, pembimbing yang baik berarti mau menghargai pekerjaan bawahannya. Bagi bawahan, pembimbing sering dianggap sebagai pembimbing dan sekaligus sebagai orang tuanya. (3) Teman sekerja (workers), merupakan faktor yang berhubungan dengan pegawai, atasan dan pegawai lainnya baik yang sama maupun berbeda jenis pekerjaannya; 4) promosi (promotions), merupakan faktor yang berhubungan dengan ada tidaknya kesempatan untuk memperoleh peningkatan kinerja selama bekerja; 5) gaji (pay), merupakan faktor pemenuhan keperluan biaya hidup pegawai yang dianggap layak atau tidak.

Davis (1993), merumuskan ada dua faktor yang mempengaruhi prestasi, yaitu: (1) faktor kemampuan (ability) pegawai terdiri dari kemampuan potensi (IQ) dan kemampuan realitas (knowledge and skill); (2) faktor motivasi, yaitu terbentuk dari sikap (attitudes) seseorang dalam menghadapi 
situasi kerja. Motivasi merupakan keadaan yang menggerakkan diri pegawai yang terarah untuk mencapai tujuan organisasi. Bernardin and Russel (1993), ada enam faktor yang dinilai dalam prestasi, yaitu: (1) high, merupakan tingkat sejauh mana proses atau hasil pelaksanaan aktivitas mendekati kesempurnaan atau mendekati tujuan yang diinginkan; (2) kuantitas, merupakan jumlah yang dihasilkan; (3) ketepatan waktu, adalah sejauh mana aktifitas dapat diselesaikan pada jenjang waktu yang dikehendaki; (4) aktifitas biaya, sejauh mana penggunaan sumber organisasi (keuangan, teknologi dan material) untuk mencapai hasil yang tertinggi; (5) mampu bekerja dengan baik tanpa memerlukan pengawasan dan bimbingan untuk mencegah tindakan yang kurang produktif; (6) hubungan antara pekerja meliputi sejauh mana pegawai memelihara harga diri, nama baik dan kerjasama di antara rekan kerja dan bawahan.

Nawawi (2003), kehidupan manusia yang sesuai dengan martabatnya dapat diperhatikan dari berbagai segi, yaitu: (1) memenuhi keperluan minimal untuk hidup secara jasmani. Keperluan itu berhubungan dengan kebutuhan makan, pakaian dan rumah untuk dapat hidup sehat secara jasmaniah. Keperluan tersebut dipengaruhi oleh kesempatan untuk beristirahat, sesuai dengan keperluan hidup sehat, termasuk juga kebutuhan rekreasi dalam bentuk kehidupan berkeluarga yang harmonis; (2) keperluan hidup dengan perasaan tenang, aman dan damai secara psikologis di lingkungan masyarakat masing-masing. Atas dasar itu, aspek perasaan tersebut memerlukan keadaan masyarakat yang bebas dari pada tekanan dan ancaman kepada setiap individu, baik terhadap jasmaninya maupun suasana batinnya. Tekanan dan ancaman terhadap suasana batin menyentuh banyak aspek yang berhubungan dengan masa sekarang dan kepastian masa depan. Setiap manusia memerlukan perasaan bebas dari ancaman yang mengganggu hak milik individu, kehilangan pekerjaan, kesediaan memperoleh pendidikan dan lain-lain; (3) keperluan spiritual dalam menjalankan agama yang diyakini, terutama bagi orangorang yang beriman.

Dalam kenyataannya dilingkungan masyarakat, sejarah membuktikan bahwa di lingkungan masyarakat yang anggotanya terdiri dari orang-orang yang beriman, kebebasan selalu diberikan kepada anggota masyarakatnya untuk menjalankan agama masing-masing. Masyarakat beriman hanya menolak orang-orang yang tidak bertuhan. Sebaliknya, di lingkungan masyarakat yang tidak beriman terutama yang tidak bertuhan, ada kecenderungan untuk selalu menekan dan memusuhi orang-orang beriman serta berusaha merampas kebebasannya dalam melaksanakan ajaran agama.

Kehidupan yang sesuai dengan martabat manusia erat hubungannya dengan hak asasi manusia (HAM), yaitu: (1) Hak untuk mendapatkan pendidikan terutama bagi manusia yang belum memasuki usia kerja. Dengan mendapatkan pendidikan formal yang memadai dan sesuai pula dengan pasar kerja di masyarakat, maka diperoleh jaminan untuk memperoleh pekerjaan. (2) Hak untuk mendapatkan gaji yang layak dalam bekerja dengan pihak lain, sesuai dengan jenis dan sifat pekerjaan yang dikerjakan. Untuk melindungi hak asasi ini, pemerintah biasanya menetapkan peraturan tentang gaji minimal. Hak asasi ini berhubungan pula dengan hak untuk mendirikan usaha, baik secara perorangan maupun kelompok. (3) Hak asasi untuk diperlakukan secara adil terutama dalam bekerja. Untuk itu perlu diatur ketentuan tentang jam kerja untuk memberi kesempatan beristirahat baik selama melaksanakan pekerjaan dan diluar jam kerja, maupun berdasarkan jangka waktu tertentu berupa pemberian hak cuti dalam berbagai bentuk. (4) Hak asasi keselamatan dan kesehatan kerja, yaitu managemen tidak boleh mengabaikan keselamatan dan kesehatan pekerjanya selama bekerja terutama waktu berada di tempat kerja. Keselamatan dan kesehatan kerja itu berhubungan dengan peralatan yang dipergunakan, bahanbahan yang dihadapi, keadaan ruang dan fasilitas. Disamping itu, managemen juga tidak dibenarkan berbuat sesuatu yang dapat menyakiti fisik dan memberikan tekanan 
psikologis. (5) Hak untuk menunaikan ajaran agama, baik dalam mendapatkan pekerjaan dan selama melaksanakan pekerjaan. Sehubungan dengan itu berarti agama tidak boleh dijadikan dasar untuk menolak atau menerima seseorang yang telah memenuhi persyaratan yang telah ditentukan. Disamping itu, bagi para pekerja yang harus menunaikan ibadah menurut ajaran agamanya selama bekerja, maka seharusnya diberikan kesediaan dengan pengaturan yang cermat dan tertib. (6) Hak untuk diperlakukan secara sama dan obyektif dalam pengembangan kinerja.

Dengan demikian, setiap pekerja yang menuhi persyaratan yaitu prestasi kerja, dedikasi, loyalitas dan syarat lainnya harus diberi kesempatan yang sama dalam menempati kedudukan tertentu dalam struktur organisasi tempat bekerja. Hal ini berhubungan pula dengan hak untuk mendapatkan kesediaan mengikuti pelatihan untuk mengisi kedudukan penting. Hal ini sangat besar pengaruhnya pada jumlah penghasilan yang dapat diterima, yang langsung atau tidak langsung akan mempengaruhi pula terhadap tingkat kesejahteraan material, untuk dapat menjalankan kehidupan sesuai dengan martabat manusia.

Berdasarkan temuan penelitian terdahulu menurut Kistyanto (2008) menganalisis pengaruh modal sosial terhadap sponsor kinerja, pengaruh modal sosial terhadap keberhasilan kinerja, sponsor kinerja terhadap keberhasilan kinerja, dan pengaruh tidak langsung modal sosial terhadap ke berhasilan melalui sponsor kinerja 232 instrumen disebar kepada pengurus sebanyak 108 instrumen yang kembali. Hasil analisis bahwa modal sosial berpengaruh secara positif terhadap sponsor kinerja dan keberhasilan kinerja. Sponsor kinerja berpengaruh terhadap keberhasilan kinerja dan terdapat pengaruh tidak langsung modal sosial terhadap keberhasilan kinerja melalui sponsor kinerja. Sponsor kinerja berpengaruh signifikan terhadap keberhasilan kinerja.

Tujuan penelitian Chin (2006), ingin mengetahui dan menjelaskan pengaruh antara tingkat kepuasan upah, kepuasan kerja, komitmen organisasi, dan berhenti kerja (kecenderungan pensiun) pada pekerja tingkat awal dan tingkat menengah di industri perbankan Taiwan serta ciri atau karakteristik demografi mereka untuk menguji kepuasan pembayaran gaji, kepuasan kerja, komitmen organisasi dan teori pergantian. Disamping itu juga ingin menjelaskan tentang beberapa masalah yang disebabkan adanya teori yang berbeda, dan ingin mengetahui apakah kepuasan upah berpengaruh dan mempunyai dampak yang signifikan terhadap kecenderungan berhenti kerja. Hasil analisis menunjukkan bahwa kepuasaan upah tidak mempunyai pengaruh positif dengan niat berhenti kerja, kepuasaan kerja tidak mempunyai suatu pengaruh positif dengan niat berhenti kerja. Komitmen organisasi mempunyai suatu pengaruh negatif dengan niat berhenti kerja, kepuasan upah mempunyai pengaruh positif dengan kepuasan kerja, kepuasan upah tidak mempunyai pengaruh yang positif secara langsung dengan komitmen organisasi, kepuasan kerja mempunyai pengaruh positif dengan komitmen organisasi, komitmen organisasi adalah penghubung antara kepuasan kerja dan niat berhenti kerja, jenis pekerjaaan mempunyai pengaruh negatif dengan niat/keinginan berhenti kerja, promosi, pengawasan, jaminan sosial, teman kerja dan komunikasi tidak mempunyai pengaruh positif dengan niat berhenti kerja, baik komitmen efektif dan komitmen normatif mempunyai pengaruh negatif yang kuat dengan niat berhenti kerja, jumlah uang ekstra (bonus) yang diberikan kepada pekerja dapat merubah pada tingkat yang spesifik niat berhenti kerja.

\section{RERANGKA KONSEPTUAL}

Menurut Amstrong (2007), ada dua faktor yang mempengaruhi prestasi yaitu; (a) faktor kemampuan (ability), pegawai terdiri dari kemampuan potensi (IQ) dan pengetahuan dan keterampilan (Knowledge and skill); (b) faktor motivasi yaitu terbentuk dari sikap (attitudes) seseorang dalam menghadapi situasi kerja. Motivasi merupakan keadaan yang mendorong seseorang untuk menggerakkan diri pribadinya melakukan 
sesuatu kegiatan yang terarah untuk mencapai tujuan organisasi.

Dalam kehidupan manusia modern atau maju, kesempatan untuk mencari kepuasan hidup yang sesuai dengan martabat manusiawi tidaklah mudah. Manusia tidak dapat hidup sendiri, karena memiliki dorongan sosial untuk hidup bersama tanpa memiliki alternatif lain. Kehidupan manusia yang sesuai dengan martabatnya (kepuasan hidup yang layak) boleh diperhatikan dari beberapa segi yaitu; (a) memenuhi keperluan minimal untuk hidup secara jasmani, (b) keperluan hidup dengan perasaan tenang, aman dan damai secara psikologi dilingkung an masyarakat masing-masing, dan (c) keperluan spiritual dalam menjalankan agama yang diyakini, terutama bagi orang-orang yang beriman. Kepuasan hidup sesorang hanya akan terwujud jika martabatnya sebagai manusia dapat terpenuhi sesuai keinginan/harapan yang dicita-citakan. Di dalam lingkungan masyarakat yang kehidupannya telah mengenal hukum, untuk dapat membantu setiap anggota masyarakatnya mewujudkan martabat manusia telah dirumuskan ketentuan-ketentuan tentang "Hak Asasi Manusia (HAM)". Usaha mewujudkan hak-hak asasi manusia tidaklah mudah karena selalu ditemui anggota masyarakat yang tidak mampu melaksanakannya, bahkan juga tidak mampu menghormati dan menghargai hak asasi orang lain.

Untuk menganalisis pengaruh faktor modal sosial, manfaat modal sosial dan modal manusia terhadap kepuasan hidup tenaga akademik perguruan tinggi Jawa Timur maka kerangka konseptual penelitian disajikan dalam gambar 2 .

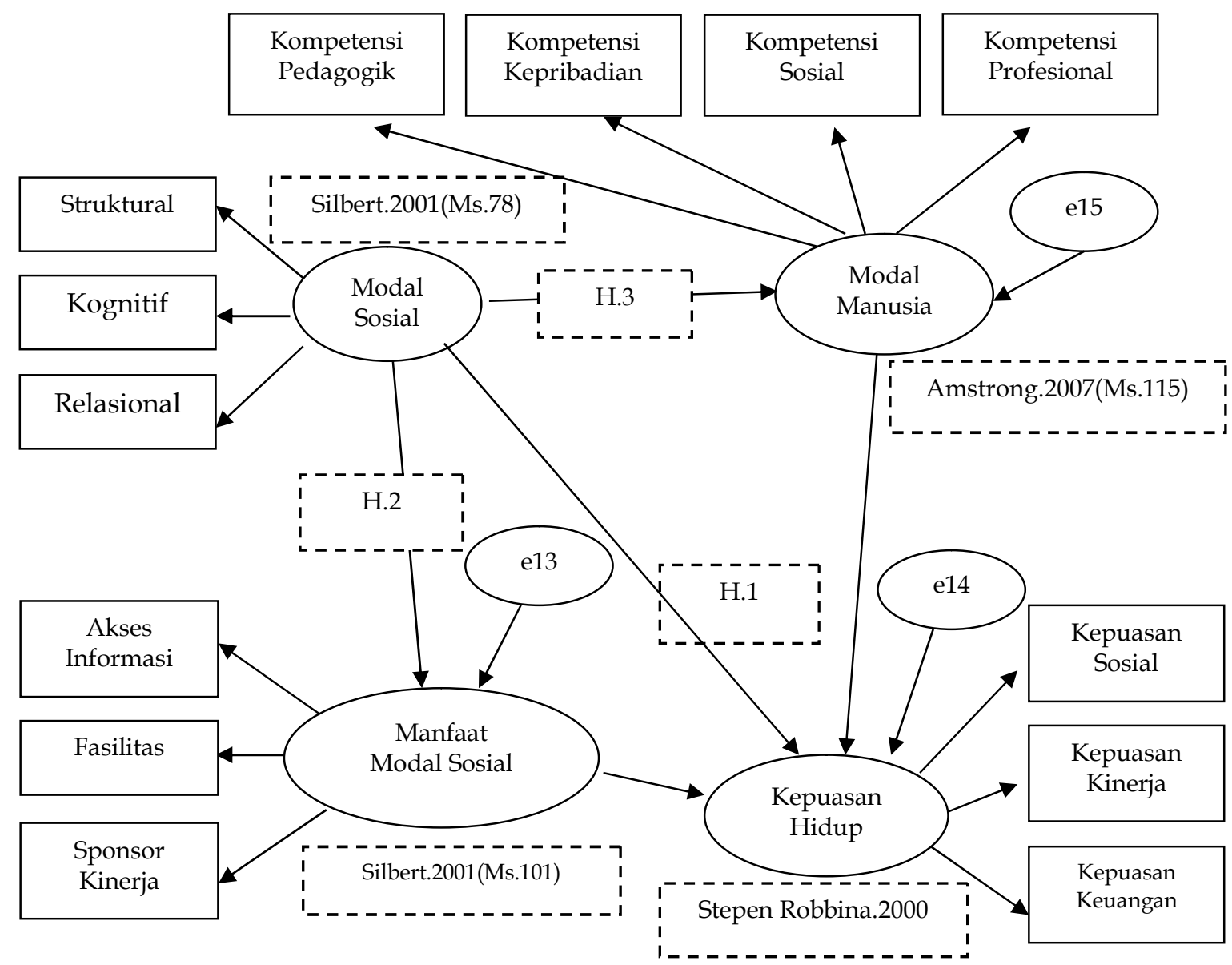

Gambar 2

Rerangka Konseptual Penelitian

Sumber : Konsep peneliti yang akan diujikan melalui analisis SEM 


\section{METODE PENELITIAN}

Jenis penelitian yang digunakan adalah Exploratory Research yaitu penelitian yang bertujuan untuk memberikan penjelasan (exploratory atau confirmatory). Penelitian explanatory adalah untuk memberikan penjelasan causal atau pengaruh antara variabel melalui uji hipotesis. Populasi penelitian ini adalah seluruh tenaga akademik yang sedang bekerja di Perguruan Tinggi Negeri Jawa Timur, yaitu; di sembilan Perguruan Tinggi dengan jumlah tenaga akademik sebanyak 6.915 orang.

Tehnik pengambilan sampel ini menggunakan teknik opportunistic sampling, dengan alasan karena sampel bersifat homogen, layak, memiliki peluang dan kesediaan yang sama, dapat dilaksanakan pada waktu sesuai dengan kondisi universitas masingmasing. Jumlah sampel dalam analisis Structural Equation Modeling (SEM) tak diperkenankan lebih dari 300 responden. Oleh karena itu, dipilih $4.3 \%$ dari populasi sejumlah 6,915 yaitu sejumlah 297 responden (Ghozali, 2008). Teknik pengumpulan data penelitian ini adalah melalui observasi, angket dan wawancara.

\section{Teknik Analisis Data}

Analisis yang digunakan dalam penelitian ini adalah Structural Equation Modeling (SEM) dengan alasan sebagai berikut; Model persamaan Structural Equation Modeling adalah generasi kedua teknik analisis multivariate yang memungkinkan penelitian untuk mengkaji pengaruh antara variabel yang kompleks baik recursive maupun non recursive untuk memperoleh gambar an menyeluruh mengenai keseluruhan model. Tidak seperti analisis multivariate biasa (regresi berganda, analisis faktor), Structural Equation Modeling dapat mengkaji secara bersama-sama), yaitu: (1) model struktural; pengaruh antara construct (yaitu; variabel laten/unobserved yang tidak dapat diukur secara langsung dan memerlukan beberapa indikator atau proxy untuk mengukurnya) baik yang bersifat independen maupun dependen; (2) model measurement, pengaruh (nilai loading) antara indikator dengan construct (variable laten).

Digabungkannya penelitian model struktural dan pengukuran tersebut memungkinkan peneliti untuk; (1) menguji kesalahan pengukuran (measurement error) sebagai bagian yang tidak boleh dipisahkan dari Structural Equation Modeling; (2) melakukan analisis faktor bersamaan dengan pengujian hipotesis. Structural Equation Modeling dapat dianggap sebagai suatu alat statistik yang sangat berguna bagi para peneliti pada seluruh bidang ilmu sosial (ekonomi, sosiologi, antropologi, psikologi dan lain-lain sebagainya). Structural Equation Modeling telah menjadi suatu "kemestian" untuk penelitian non exsperimental dimana rumus untuk menguji teori belum dikembangkan secara menyeluruh. Sehingga, kini terdapat banyak sekali software yang menawarkan Structural Equation Modeling.

Struktural Equatiohn Modeling memiliki dua tujuan utama dalam analisisnya. Tujuan pertama adalah; untuk menentukan model plausible (masuk akal) atau fit; atau dengan bahasa yang lebih mudah, apakah model "benar" berdasarkan suatu data yang diperoleh dari responden, sedangkan tujuan kedua, adalah untuk menguji hipotesis yang telah ditentukan atau dibuat sebelumnya. Ada tujuh langkah yang harus dilakukan apabila menggunakan Structural Equation Modeling yaitu; (1) pengembangan suatu model berdasarkan teori; (2) menyusun parth diagram untuk menyatakan pengaruh kausalitas; (3) menterjemahkan path diagram ke dalam persamaan struktural dan spesifikasi model pengukuran; (4) memilih matriks input dan model/teknik perkiraan; (5) menilai problem identifikasi; (6) Evaluasi criteria goodness of fit; (7) interpretasi dan modifikasi model. Menurut Ghozali (2008), Structural Equation Modeling tepat untuk: (1) mengesahkan unidimensionality dari berbagai indikator untuk sesuatu dimensi / construct/konsep/ faktor; (2) menguji kesesuaian/ketepatan sesuatu model berdasarkan data empirik yang dikaji; (3) menguji kesesuaian model sekaligus pengaruh causality antara faktor yang diteliti dalam model tersebut. 


\section{ANALISIS DAN PEMBAHASAN}

Berdasarkan hasil analisis yang diperoleh dari pengujian hipotesis, menunjukkan bahwa terdapat pengaruh yang signifikan antara variabel bebas modal sosial secara keseluruhan dengan variabel terikat kepuasan hidup tenaga akademik. Bila merujuk pada penilaian normalitas secara multivariate nilai crital ratio kurtosis bernilai $-2,493$ sehingga dapat disimpulkan berdistribusi secara normal karena di antara -2,58 hingga 2,58 . Merujuk pada regression weights pengaruh variabel modal sosial $(X)$ dengan variabel kepuasan hidup tenaga akademik (Y3) $\mathrm{P}=0,037$ maknanya terdapat pengaruh yang signifikan. Selanjutnya merujuk interpretasi model full model ada tiga kriteria yang baik $\mathrm{P}=<0,05$ atau 0,00 , RMSEA $<0,08$ atau 0.079 dan Tucker Lewis Index (TLI) >0,95 atau 0,982, maknanya model dapat dikatakan baik bila memenuhi sekurang-kurangnya dua kriteria fit measure. Dari Hasil penelitian dimensi stuktural $\left(\mathrm{X}_{17}, \mathrm{X}_{16}, \mathrm{X}_{15}, \mathrm{X}_{14}, \mathrm{X}_{13}, \mathrm{X}_{12}, \mathrm{X}_{11}\right)$, dimensi relasional $\left(X_{31}, X_{33}, X_{34}, X_{35}, X_{36}, X_{37}\right.$, $\left.X_{310}, X_{311}, X_{312}\right)$, dimensi kognitif $\left(X_{24}, X_{23}, X_{22}\right.$, $\left.X_{21}\right) \quad P=<0,05$ artinya sangat signifikan, sedangkan untuk empat item dimensi relasional yaitu $X_{38} P=<0,05$ yaitu $0,02, X_{39}$ $\mathrm{P}=<0,05$ yaitu $0,09, \mathrm{X}_{313} \mathrm{P}=<0,05$ yaitu 0,042 dan $\mathrm{X}_{314} \mathrm{P}=<0,05$ yaitu 0,001 . Variabel kepuasan hidup tenaga akademik terhadap kepuasan sosial $\left(\mathrm{Y}_{312}, \mathrm{Y}_{313}, \mathrm{Y}_{314}, \mathrm{Y}_{314}\right) \mathrm{P}=<0,05$ dan kepuasan kinerja $\left(Y_{322}, Y_{323}, Y_{324}, Y_{325}\right)$ $\mathrm{P}=<0,05$, kepuasan keuangan $\left(\mathrm{Y}_{332}, \mathrm{Y}_{333}, \mathrm{Y}_{334}\right.$, $\left.\mathrm{Y}_{335}\right) \mathrm{P}=<0,05$ yaitu 0,03 .

Penelitian lain yang mendukung adalah Robbins (2003), menunjukkan bahwa kepuasan terjadi apabila keperluan biaya individu sudah terpenuhi dan berkait dengan tingkat kepuasan dikaitkan dengan pegawai, merupakan sikap umum yang dimiliki oleh pegawai yang erat kaitannya dengan imbalan-imbalan yang mereka yakini akan mereka terima setelah melakukan sebuah pengorbanan. Dari pendapat Robbins tersebut terkandung dua dimensi pertama kepuasan yang dirasakan individu yang titik beratnya individu anggota masyarakat. Dimensi kedua adalah kepuasan yang merupakan sikap umum yang dimiliki oleh pegawai.
Penelitian Kistyanto (2008), juga mendukung hasil penelitian ini, menguraikan bahwa; modal sosial berpengaruh positif terhadap sponsor kinerja dan keberhasilan kinerja. Sponsor kinerja berpengaruh terhadap keberhasilan sebuah kinerja dan terdapat pengaruh tidak langsung modal sosial terhadap keberhasilan sebuah kinerja melalui sponsor kinerja. Sponsor kinerja berpengaruh signifikan terhadap keberhasilan kinerja.

Hasil penelitian ini menunjukkan bahwa modal sosial yaitu dimensi struktural, kognitif dan relasional mempunyai pengaruh signifikan dengan kepuasan hidup tenaga akademik yang diukur dari kepuasan sosial, kinerja dan keuangan tenaga akademik di Perguruan Tinggi Negeri Jawa Timur. Atas dasar hasil penelitian tersebut, garis penghubung antara variabel modal sosial sebagai variabel bebas dengan variabel kepuasan hidup sebagai variabel terikat masih tetap dapat dipertahankan untuk model konseptual hasil penelitian.

Berdasarkan hasil analisis yang diperoleh dari pengujian hipotesis, menunjukkan bahwa antara variabel bebas modal sosial dan manfaat modal sosial sebagai variabel mediator dengan variabel terikat kepuasan hidup tenaga akademik, berdasarkan penilaian normalitas menunjukkan bahwa secara multivariate nilai kritikal ratio kurtosis benilai $-1,400$, sehingga dapat disimpulkan berdistribusi secara normal karena di antara $-2,58$ hingga 2,58. Bila melihat dari intrepretasi model full model ada dua kriteria yang baik yaitu $\mathrm{P}=<0,05$ atau 0,00 , Tucker Lewis Index (TLI) >0,95 atau 0,979 disebut marginal fit, hal ini dapat dikatakan baik karena telah memenuhi sekurang-kurangnya dua kriteria fit measure.

Dari Hasil penelitian variabel modal sosial terhadap dimensi stuktural $\left(X_{17}, X_{16}\right.$, $\left.X_{15}, X_{14}, X_{13}, X_{12}, X_{11}\right)$, dimensi relasional (X31, $\left.X_{33}, X_{34}, X_{35}, X_{36}, X_{37}, X_{310}, X_{311}, X_{312}\right)$, dimensi kognitif $\left(X_{24}, X_{23}, X_{22}, X_{21}\right) P=<0,05$ artinya sangat signifikan, sedang- kan untuk empat item dimensi relasional yaitu $X_{38} P=<0,05$ yaitu 0,02, $X_{39} \quad P=<0,05$ yaitu $0,09, X_{313}$ $\mathrm{P}=<0,05$ yaitu 0,042 dan $\mathrm{X}_{314} \mathrm{P}=<0,05$ yaitu 0,001 , Variabel manfaat modal sosial 
terhadap akses informasi $\left(\mathrm{Y}_{111}, \mathrm{Y}_{112}, \mathrm{Y}_{113}\right.$, $\left.\mathrm{Y}_{114}\right)$, akses sumber daya $\left(\mathrm{Y}_{121}, \mathrm{Y}_{122}, \mathrm{Y}_{123}\right)$, sponsor kinerja $\left(Y_{31}, Y_{132}, Y_{133}, Y_{134}, Y_{135}, Y_{135}\right.$, $\mathrm{Y}_{137}$ ). Dan Variabel kepuasan hidup tenaga akademik terhadap kepuasan sosial $\left(\mathrm{Y}_{312}\right.$, $\left.\mathrm{Y}_{313}, \mathrm{Y}_{314}, \mathrm{Y}_{314}\right) \mathrm{P}=<0.05$ dan kepuasan kinerja $\left(Y_{322}, Y_{323}, Y_{324}, Y_{325}\right) \quad P=<0.05$, kepuasan keuangan $\left(\mathrm{Y}_{332}, \mathrm{Y}_{333}, \mathrm{Y}_{334}, \mathrm{Y}_{335}\right) \mathrm{P}=<0,05$ yaitu 0,03 .

Bila diperhatikan pada regression weig$h t s$, nilai probabilitas dari pengaruh variabel modal sosial $(X)$ terhadap variabel manfaat modal sosial $\left(\mathrm{Y}_{1}\right) \mathrm{P}=0,065$ lebih besar dari 0,05 (tidak signifikan), pengaruh variabel modal sosial $(X)$ terhadap variabel kepuasan hidup tenaga akademik $\left(\mathrm{Y}_{3}\right) \mathrm{P}=<0,05$ atau 0,038 , pengaruh variabel manfaat modal sosial $\left(Y_{1}\right)$ terhadap variabel kepuasan hidup tenaga akademik $\left(\mathrm{Y}_{3}\right) \mathrm{P}=0,045$. Maknanya pengaruh variabel modal sosial $(X)$ dan variabel manfaat modal sosial $\left(Y_{1}\right)$ ada persoalan, atau pengaruh variabel modal sosial (X) dan variabel kepuasan hidup tenaga akademik $\left(\mathrm{Y}_{3}\right)$ terjadi gangguan setelah variabel manfaat modal sosial $\left(\mathrm{Y}_{1}\right)$ menjadi mediator. Hal ini dapat terbukti yaitu terjadinya perubahan yang semula $\mathrm{P}=0,037$ menjadi $\mathrm{P}=0,038$ atau ada selisih 0,001 .

Berdasarkan dari hasil penelitian menunjukkan bahwa terjadinya persoalan tentang pengaruh tersebut disebabkan karena kemampuan yang dimiliki oleh tenaga akademik berpengaruh terhadap variabel modal sosial meliputi faktor struktural, yaitu; tenaga akademik yang memiliki link secara personal maupun kelembagaan; faktor kognitif, yaitu: kemampuan berkomunikasi, tutur kata sopan dan santun, menerima pendapat orang lain; faktor relasional, yaitu: tenaga akademik yang bertanggungjawab, konsisten antara bicara dan sikap atau tindakan, mampu memegang amanah, jujur dan dalam bersikap merujuk pada kode etik tenaga akademik tidak ada pengaruh signifikan dengan variabel manfaat modal sosial meliputi faktor akses informasi, yaitu: meliputi kemampuan mengakses informasi secara pantas, cepat dan tepat; faktor sumber daya sosial, yaitu: mampu memanfaatkan informasi yang berpengaruh terhadap keuangan dan fasilitas; faktor sponsor kinerja, yaitu: mampu memiliki atau pengaruh terhadap kolega senior/mentor, peluang memperoleh kinerja yang lebih baik dari pelaksanaan tugas dan kewajiban sebagai tenaga akademik secara profesional.

Pengaruh faktor-faktor dari variabel modal sosial dan faktor-faktor dari variabel manfaat modal sosial lebih ditentukan oleh pengaruh personal/individu atau kumpulan individu tenaga akademik dengan pihak pemegang kebijakan dari manajemen perguruan tinggi untuk proses pengembangan pribadi dan kegiatan tenaga akademik dalam industri perguruan tinggi baik secara internal maupun eksternal. Pengaruh atau ikatan kedekatan tenaga akademik tersebut karena kesamaan etnik, suku, ras, agama, almamater, keluarga/persaudaraan, satu keyakinan, budaya dan politik, daerah, ikatan kumpulan/organisasi, dan atau pandangan tertentu, lebih berpengaruh positif dari kemampuan yang dimiliki seseorang tenaga akademik.

Kemampuan yang dimiliki seseorang tenaga akademik yang berhubungan dengan faktor-faktor variabel modal sosial tidak ada pengaruh signifikan dengan faktor-faktor variabel manfaat modal sosial. Hal tersebut terjadi jika tenaga akademik tidak termasuk dalam sistem atau kumpulan pemegang kebijakan manajemen perguruan tinggi.

Berdasarkan hasil penelitian menunjukkan bahwa; bila tenaga akademik memiliki kemampuan memanfaatkan informasi strategik meliputi peluang promosi, menyambung, latihan, conference akan dapat meningkatkan jabatan fungsional, pangkat, kesempatan mendapatkan proyek penelitian dan pengabdian kepada masyarakat serta memperoleh tambahan pendapatan. Bila mempunyai kemampuan memperoleh kemudahan mengakses bidang finansial dan fasilitas dari lembaga, berbagai fasilitas/ bantuan dalam melaksanakan pekerjaan, per jalanan dinas, menyambung pelajaran dan spesialisasi, pencarian dana proyek penelitian dan pengabdian kepada masyarakat merupakan suatu peluang untuk meningkatkan jabatan fungsional/pangkat dan tambahan pendapatan. Bila dapat memiliki kolega senior/mentor yang dapat memberikan 
dukungan terhadap peningkatan kinerja, merupakan peluang untuk memperoleh peningkatan jabatan struktural atau tugas tambahan dan jabatan fungsional serta mem peroleh tambahan pendapatan.

Beberapa penelitian terdahulu yang mendukung berpengaruhnya antara manfaat modal sosial dengan kepuasan hidup, antara lain; hasil penelitian dari Seibert et al., (2001), menunjukkan bahwa dua ukuran struktur jaringan yaitu ikatan lemah dan lubang struktural secara positif berpengaruh terhadap tahap sumber daya sosial yang tertanam dalam jaringan seseorang, dimana sumber daya sosial diukur sebagai jumlah kontak/ikatan dalam upaya melakukan pengembangan suatu lingkungan, fungsi lain dalam organisasi dan pada tahap yang lebih tinggi dalam organisasi. Sumber daya sosial pada tahap berikutnya berpengaruh positif terhadap gaji yang diterima saat ini, jumlah promosi yang diterima selama masa kinerjanya dan kepuasan kinerja melalui pengaruh positif terhadap variabel manfaat jaringan yaitu akses tentang informasi, sumber daya sosial dan sponsor kinerja. Segall (2010), berdasarkan hasil penelitiannya menemukan bahwa penggunaan mentor mempunyai kesan/pengaruh yang bersifat positif terhadap kepuasan kerja/keberhasilan sebuah kinerja secara objektif maupun kepuasan/ keberhasilan kinerja secara objektif.

Berdasarkan dari hasil analisis yang diperoleh dari pengujian hipotesis, menunjukkan bahwa antara variabel modal sosial dan modal manusia sebagai variabel mediator dengan variabel terikat kepuasan hidup tenaga akademik, berdasarkan penilaian normalitas secara multivariate nilai kritikal ratio kurtosis -1,980, sehingga dapat disimpulkan berdistribusi secara normal karena di antara $-2,58$ hingga 2,58, Bila dilihat dari regression weights pengaruh variabel modal sosial $(X)$ terhadap variabel modal manusia $\left(\mathrm{Y}_{2}\right) \mathrm{P}=0,40<0,05$, variabel modal manusia $\left(\mathrm{Y}_{2}\right)$ terhadap variabel kepuasan hidup tenaga akademik $\left(\mathrm{Y}_{3}\right) \mathrm{P}=0,42<0,05$, Variabel modal sosial $(X)$ terhadap variabel kepuasan hidup tenaga akademik $\left(\mathrm{Y}_{3}\right) \mathrm{P}=$ $0,038<0,05$ maknanya ada pengaruh signifikan dari ketiga variabel. Walaupun ada selisih tingkat signifikan pengaruh antara variabel modal sosial $(X)$ dan variabel kepuasan hidup tenaga akademik $\left(\mathrm{Y}_{3}\right)$ yaitu 0,001 (semula 0,037 jadi 0,038) setelah modal manusia $\left(Y_{2}\right)$ sebagai variabel mediator. Bila dilihat pada intrepretasi model, full model terdapat tiga kriteria yang baik yaitu probabilitas $<0,05$ atau 0,00 dan RMSEA $<0,08$ atau 0,061 dan TLI $>0,95$ atau 0,957 , maknanya model dapat dikatakan baik karena masih ada sekurang-kurangnya dua kriteria fit measure.

Pengaruh variabel modal sosial terhadap ketiga dimensi struktural, kognitif dan relasional terdapat pengaruh signifikan $\mathrm{P}=<0,05$, yaitu pengaruh variabel modal manusia dengan kompetensi pedagogik, kompetensi kepribadian, kompetensi sosial dan kompetensi profesional tenaga akademik menunjukkan ada pengaruh signifikan $\mathrm{P}=<0,05$, dan pengaruh variabel kepuasan hidup tenaga akademik dengan ketiga kepuasan sosial, kinerja dan keuangan terdapat pengaruh signifikan $\mathrm{P}<0,05$ dan ada 4 item dengan nilai 0,03.

Bila tenaga akademik yang memiliki link baik internal maupun eksternal, komunikatif, sopan santun, menerima pendapat orang lain, memegang amanah, terbuka dan jujur, memegang norma dan kode etik, ikhlas membantu orang lain, bersedia berkorban, menghormati hak orang lain dan solid dalam pengaruh team work, mempunyai peluang memperoleh kesempatan meningkatkan jenjang pendidikan, menambah wawasan dan jaringan, pengalaman kerja, serta memiliki kompetensi minimal kepribadian, sosial dan profesional. Bila tenaga akademik yang memiliki kompetensi pedagogik dan jenjang pendidikan doktor, memiliki kompetensi kepribadian, profesional dan pengalaman, akan lebih mudah memperoleh kesempatan/peluang peningkatan jabatan fungsional dan pangkat, jabatan struktural, proyek penelitian dan pengabdian kepada masyarakat, tugas-tugas tambahan, mengikuti kegiatan ilmiah, penulisan karya tulis yang dipublikasikan serta tambahan pendapatan.

Bila diperhatikan dari pada selisih tingkat signifikan 0,001, hal ini menunjukkan 
bahwa ada faktor gangguan/persoalan walaupun kecil dan perbedaan tersebut di atas dapat disebabkan faktor latar belakang pendidikan, pengalaman kerja/lama masa pengabdian dan kompetensi tenaga akademik terhadap kepuasan hidup tenaga akademik.

Beberapa pengaruh tersebut antara lain, pertama dengan keluarnya Peraturan Menteri Pendidikan Nasional N0. 27 tahun 2005 dan Surat Direktorat Jenderal Pendidikan Tinggi No.1785/D/C/2006 bahwa yang dapat diangkat sebagai guru besar adalah yang memiliki ijasah doktor dan memiliki kepangkatan lektor kepala atau lektor, kedua dari segi kompetensi bahwa tenaga akademik sangat memerlukan peningkatan keempat kompetensi dalam rangka upaya meningkatkan berbagai kemampuan akademik dan peningkatan kinerja baik dilingkungan perguruan tinggi maupun tugas diluar perguruan tinggi, ketiga bilamana secara yuridis/formal memiliki ijasah tenaga akademik akan memperoleh tambahan pendapatan/gaji.

Sebab itu, sesuai program yang sudah dicanangkan oleh Kementerian Pendidikan secara bertahap berupaya untuk tenaga akademik dan kependidikan sesuai anggaran yang tersedia ditingkatkan kompetensi yang dimiliki tenaga akademik dan sekaligus memberikan peningkatan kesejahteraan tenaga akademik yang telah memiliki ijazah kelayakan tenaga akademik.

Atas dasar hasil penelitian tersebut menunjukkan bahwa garis penghubung antara variabel modal sosial dengan variabel modal manusia sebagai variabel mediator dan variabel kepuasan hidup sebagai variabel terikat masih dapat dipertahankan.

\section{SIMPULAN DAN SARAN}

Modal sosial sebagai variabel bebas (X) mempunyai pengaruh signifikan dengan variabel terikat kepuasan hidup tenaga akademik $\left(\mathrm{Y}_{3}\right)$, hal ini ditunjukkan bahwa $\mathrm{P}$ $=<0,05$ atau 0,037 , modal sosial sebagai variabel bebas $(X)$ tidak ada pengaruh signifikan atau terjadi persoalan dengan manfaat modal sosial sebagai variabel bebas dan mediator $\left(\mathrm{Y}_{1}\right)$, hal ini ditunjukkan bahwa $\mathrm{P}$
$=0,065$ (tidak siginifikan), modal sosial sebagai variabel bebas $(X)$ mempunyai pengaruh signifikan dengan modal manusia sebagai variabel mediator $\left(\mathrm{Y}_{2}\right)$ hal ini ditunjukkan bahwa $\mathrm{P}=0,040$. Maknanya untuk pengaruh modal manusia sebagai variabel mediator kurang berpengaruh positif. Jika diperhatikan dari nilai probabilitas yang dihasilkan, bila dibandingkan dengan pengaruh langsung antara modal sosial dengan kepuasan hidup yaitu semula $P=0,037$ setelah melalui mediator menjadi $\mathrm{P}=0,038$.

Manfaat modal sosial sebagai variabel mediator $\left(Y_{1}\right)$ tidak ada sumbangan dan pengaruh yang signifikan dengan variabel bebas modal sosial $(X)$ hal ini ditunjukkan bahwa $\mathrm{P}=0,065$ atau $>0,05$, namun manfaat modal sosial sebagai variabel bebas $\left(Y_{1}\right)$ mempunyai pengaruh yang signifikan dengan kepuasan hidup tenaga akademik sebagai variabel terikat $\left(\mathrm{Y}_{3}\right)$. Hal ini ditunjukkan bahwa $P=0,045$. Maknanya untuk pengaruh variabel bebas modal sosial dan manfaat modal sosial sebagai variabel mediator terjadi persoalan. Namun, karena interpretasi model, full model ada sekurangkurangnya dua kreteria memenuhi fit measure baik yaitu propability $0,00<0,00$ dan Tucker Lewis Index (TLI) 0,979 >0,95, maka model konseptual penelitian awal tidak perlu ada perubahan model konseptual setelah dilakukan penelitian ini, sedangkan pengaruh antara manfaat modal sosial sebagai variabel bebas dan kepuasan hidup tenaga akademik sebagai variabel terikat masih tidak terjadi persoalan maka dapat dipertahankan pula.

Modal manusia sebagai variabel bebas dan mediator $\left(\mathrm{Y}_{2}\right)$ mempunyai pengaruh signifikan dengan variabel modal sosial $(X)$ hal ini ditunjukkan bahwa $\mathrm{P}=0,040$. Modal manusia sebagai variabel bebas dan mediator $\left(\mathrm{Y}_{2}\right)$ dengan variabel terikat kepuasan hidup tenaga akademik $\left(Y_{3}\right)$ juga mempunyai pengaruh signifikan hal ini ditunjukkan bahwa $\mathrm{P}<0,042$. Dari hasil penelitian ini menunjukkan bahwa modal manusia sebagai variabel bebas dan mediator $\left(\mathrm{Y}_{2}\right)$ mempunyai pengaruh negatif terhadap modal sosial sebagai variabel bebas walaupun bila dibandingkan dengan pengaruh langsung 
antara modal sosial sebagai variabel bebas (X) dengan kepuasan hidup tenaga akademik sebagai variabel terikat $\left(\mathrm{Y}_{3}\right)$ menunjukkan tingkat probilitinya lebih kecil yaitu $\mathrm{P}=<0,05$ atau 0,038 .

Maknanya bila dibandingkan dengan pengaruh langsung antara variabel modal sosial $(X)$ dengan variabel kepuasan hidup tenaga akademik $\left(Y_{3}\right)$ semula $P=0,037$, kemudian setelah variabel modal manusia $\left(Y_{2}\right)$ sebagai variabel mediator $\mathrm{P}=0,038$. Hal ini menunjukkan adanya peningkatan nilai $P$ yaitu selisih 0,001.

Kepuasan hidup tenaga akademik sebagai variabel terikat $\left(\mathrm{Y}_{3}\right)$ mempunyai pengaruh siginifikan dengan ketiga variabel bebas dan mediator, yaitu dengan variabel bebas modal sosial $(X)$ hasil penelitian menunjukkan bahwa $\mathrm{P}<0,05$ atau 0,037 , dengan variabel mediator manfaat modal sosial $\left(Y_{1}\right)$ hasil penelitian menunjukkan bahwa $\mathrm{P}<$ 0,05 atau 0,045 , pengaruh dengan variabel mediator modal manusia $\left(\mathrm{Y}_{2}\right)$ hasil penelitian menunjukkan bahwa $\mathrm{P}=<0,05$ atau 0,042 . Maknanya pengaruh dari ketiga variabel tersebut, pengaruh yang paling signifikan adalah dengan variabel modal sosial
( $\mathrm{X}$ ) yaitu $\mathrm{P}=0,037$, kedua pengaruh dengan variabel modal manusia $\left(\mathrm{Y}_{2}\right)$ yaitu $\mathrm{P}=0,042$ dan ketiga atau terakhir dengan variabel manfaat modal sosial yaitu $\mathrm{P}=0,045$.

Bila dilihat pengaruh dari ketiga faktor sosial tersebut maka modal sosial yang paling signifikan dibanding dengan manfaat modal sosial dan modal manusia. Dari hasil penelitian tersebut di atas menunjukkan bahwa model konseptual awal yang digunakan sebagai dasar penelitian, tidak terdapat perubahan model konseptual penelitian, karena dari hasil penelitian menunjukkan bahwa antara variabel bebas modal sosial. Walaupun tidak terdapat pengaruh signifikan dengan variabel bebas dan mediator manfaat modal sosial akan tetapi masih didukung dari hasil intrepretasi model full model, menunjukkan ada sekurang-kurangnya dua kreteria fit measure yaitu propability $<0,05$ atau 0,00, Tucker Lewis Index (TLI) $>0,95$ atau 0,979 dan Root mean square error of approximation (RMSEA) <0,08 atau 0,073 disebut baik, Maknanya bentuk model konseptual penelitian awal masih dapat dipakai/dipertahankan seperti gambar 3 .

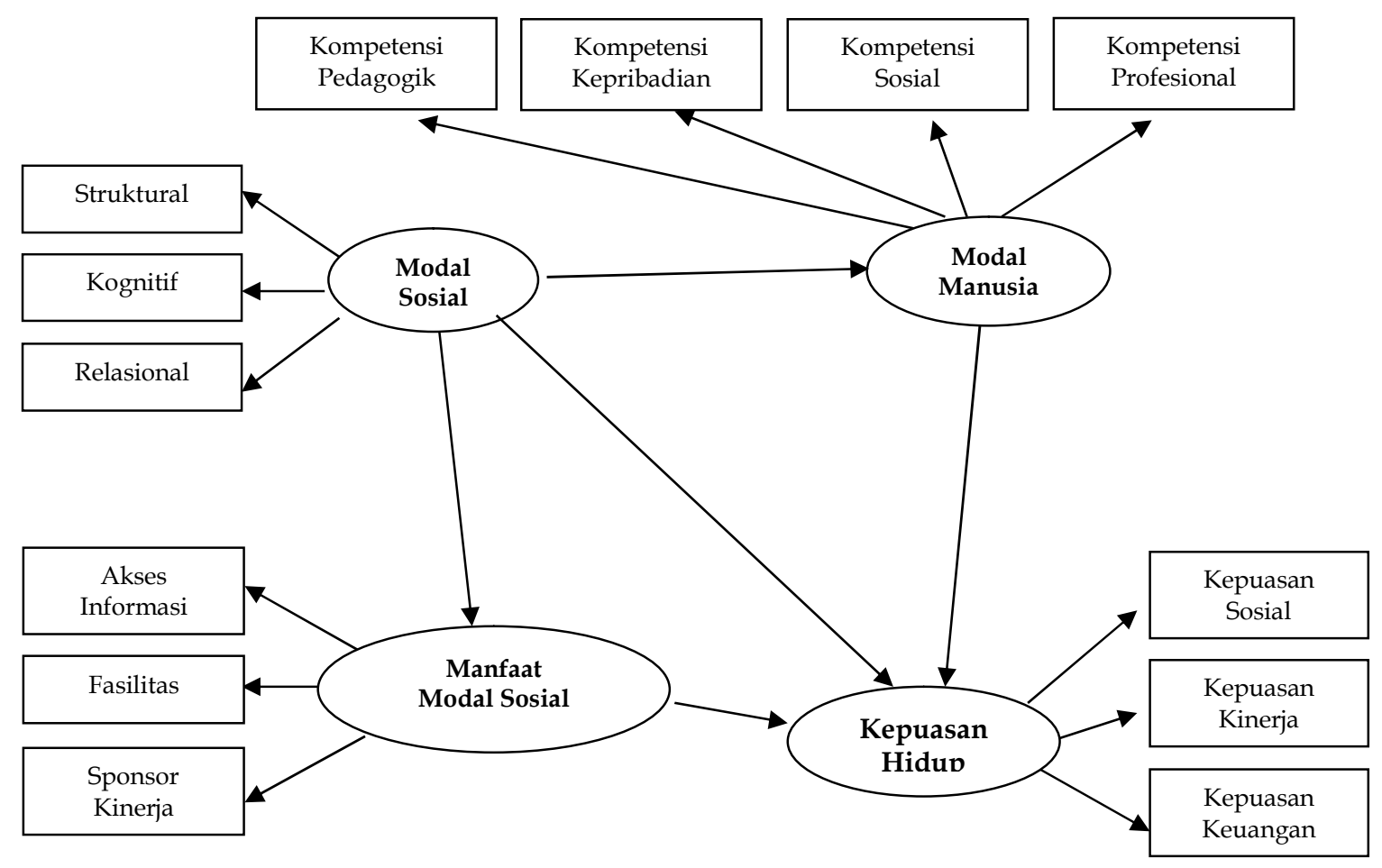

Gambar 3

Model Konseptual Hasil Penelitian

Sumber : Konsep peneliti yang akan diujikan melalui analisis SEM 
Model konseptual penelitian dapat dipertahankan karena bila diperhatikan pula dari model hasil penelitian dari keempat variabel yaitu modal sosial, manfaat modal sosial, modal manusia dan kepuasan hidup tenaga akademik diperoleh hasil bahwa penilaian normalitas secara multivariate nilai critikal ratio kurtosis bernilai -2,533, sehingga dapat disimpulkan berdistribusi secara normal karena di antara $-2,58$ hingga 2,58. Bila dilihat dari regression weight yaitu pengaruh modal sosial $(X)$ dengan manfaat modal sosial $\left(Y_{1}\right) P=0,059$, pengaruh manfaat modal sosial $\left(Y_{1}\right)$ dengan kepuasan hidup tenaga akademik $\left(\mathrm{Y}_{3}\right) \mathrm{P}=0,043$, pengaruh modal manusia $\left(\mathrm{Y}_{2}\right)$ dengan kepuasan hidup tenaga akademik $\left(\mathrm{Y}_{3}\right) \mathrm{P}=0,034$, pengaruh modal sosial $(X)$ dengan kepuasan hidup tenaga akademik $\left(\mathrm{Y}_{3}\right) \mathrm{P}=0,038$, hasil ini ada perbedaan dengan hasil regression weight setiap variabel namun tidak terlalu signifikan atau besar tingkat perbedaannya. Selanjutnya, bila diperhatikan dari interpretasi model full model probabilitas $<0,05$ atau 0,00 , Root mean square error of approximation (RMSEA) $<0,08$ atau 0,073 dan Tucker Lewis Index (TLI) $>0,95$ atau 0,979, ini menunjukkan bahwa model dapat dikatakan baik karena masih memenuhi sekurang-kurangnya dua kriteria fit measure,

Hasil penelitian ternyata model konsep penelitian masih dapat diterima, namun demikian masih perlu kajian lebih mendalam agar diketahui secara pasti penyebab adanya beberapa faktor yang kurang memberikan hasil baik, Disamping itu perlu ada kajian yang obyeknya berbeda, tapi variabel yang digunakan sama yaitu modal sosial, manfaat modal sosial dan modal manusia, apakah hasil yang diperoleh sama atau berbeda, maka akan nampak dimana letak adanya kesamaan dan atau perbedaannya, sehingga akan diperoleh hasil penelitian yang dapat digunakan sebagai rujukan untuk melakukan suatu kegiatan penelitian yang akan datang,

Berdasarkan hasil penelitian dan simpulan dimuka, maka peneliti ingin menyampaikan atau mengemukakan beberapa pendapat yang berhubungan dengan pengaruh faktor sosial yang terdiri dari modal sosial sebagai variabel bebas, manfaat modal sosial, dan modal manusia sebagai variabel bebas dan mediator dengan kepuasan hidup tenaga akademik sebagai variabel terikat,

Pertama, karena pada setiap perguruan tinggi negeri di Jawa timur memiliki kemampuan dan kebijakan internal yang berbeda-beda, karena perbedaan budaya organisasi, status akreditasi, status yuridis, manajemen perguruan tinggi, jumlah fakultas dan program study pasca sarjana, jumlah tenaga akademik dan mahasiswa, fasilitas dan kekayaan perguruan tinggi sesuai dengan perundang-undangan perguruan tinggi yang baru, maka ukuran kepuasan hidup mereka juga menunjukkan perbedaan yang signifikan. Hal ini, perlu adanya rasa saling menghargai, membantu, memberikan kesempatan sesama tenaga akademik dalam upaya meningkatkan kemampuan mencapai kepuasan hidup masing-masing. Untuk tenaga akademik yang memperoleh kesempatan sebagai pengelola perguruan tinggi, hendaknya melaksanakan amanah sesuai aturan dan kewenangannya dan memberikan keteladanan dalam upaya mencapai kepuasan hidupnya,

Kedua, dalam melaksanakan dan appreciation dimensi kognitif perlu adanya petunjuk dan kebijakan yang diberikan oleh pemegang kewenangan agar tenaga akademik mampu mengapresiasikannya secara benar bagaimana berkomunikasi atau berbicara dan menyampaikan pendapat dengan menggunakan bahasa yang mudah difahami dan tidak menimbulkan pengertian yang berbeda, berkomunikasi dengan memperhatikan tata cara dan budaya setempat, menghargai pendapat orang lain, berkomunikasi dengan maksud untuk bertukar wawasan dan pengalaman, berkomunikasi dengan memberi kesempatan orang lain saling menyampaikan pendapat, baik sesama tenaga akademik, non akademik dan masyarakat baik dalam ruang lingkup kegiatan ilmiah di kampus maupun sosial lainnya, pengaruh antar personal secara kelembagaan dan dilingkungan masyarakat, Serta agar para tenaga akademik mampu untuk melaksanakan dimensi relasional maka diperlukan ucapan dan sikap yang 
konsisten dari pemegang kebijakan terlebih dahulu sebelum mewajibkan tenaga akademik yang lain melaksanakan tugas dan kewajibannya,

Ketiga, akses informasi dapat berjalan dengan baik bilamana dari pihak lembaga atau institusi bersifat terbuka dan memberikan kesempatan kepada tenaga akademik untuk dapat mengakses informasi strategik yang berkenaan dengan pekerjaan dan tugas tenaga kademik, akses fasilitas sosial agar dapat berjalan dengan benar hendaknya pemegang hak memberikan kesempatan kepada tenaga akademik untuk mengetahui atau mendapatkan informasi secara terbuka yang berkaitan dengan bantuan keuangan mengikuti latihan, seminar nasional maupun internasional, bantuan penelitian lanjut program master dan doktor baik di perguruan tinggi dalam negeri maupun luar negeri,

Keempat, sponsor kinerja agar dapat dilaksanakan dengan benar dan baik sesuai prosedur dan ketentuan akademik maka pemegang kewenangan hendaknya dalam upaya mewujudkan persoalan yang berpengaruh dengan rekan kerja senior atau mentor dan junior dalam perguruan tinggi, memberikan kesempatan kepada semua tenaga akademik untuk dapat memiliki rekan kerja senior atau mentor yang dapat memberikan dukungan terhadap kinerja, memberikan tugas tambahan, memberikan perlindungan terhadap kinerja, nasehat bimbingan dan saran teknik terhadap pekerjaan dan tugas, wawasan spiritual dan politik dalam dunia perguruan tinggi yang erat pengaruhnya dengan pekerjaan dan kinerja tenaga akademik, atas dasar kewenangan yang dimiliki oleh pimpinan perguruan tinggi maka hal tersebut di atas perlu dijaga dan dilaksanakan sesuai dengan undangundang yang berlaku agar dalam pelaksanaan tugas dan tanggungjawab sebagai tenaga akademik dapat berjalan sesuai ketentuan akademik dan mampu menciptakan kredibilitas yang mantap, cakap dan terarah,

Kelima, dalam mewujudkan dan meningkatkan kompetensi tenaga akademik yang meliputi kompetensi pedagogik, sosial, kepribadian dan profesional, bagi tenaga akademik pemegang kewenangan hendak- nya mendorong dan memberi motivasi kepada semua tenaga akademik untuk memiliki empat kompetensi, yaitu; kompetensi pedagogik, kompetensi kepribadian, kompetensi sosial dan kompetensi profesional, Bila kegiatan tersebut yaitu keempat kompetensi yang bersifat holistik, sebagai satu badan yang kuat dan tidak boleh dipisahkan satu dengan lainnya yang diwujudkan dalam prestasi dapat dilaksanakan secara benar dan baik oleh setiap tenaga akademik merujuk pada ketentuan perundangan yang berlaku dan diberikan dukungan oleh pemegang kewenangan, maka gambaran dan pengembangan perguruan tinggi serta kepuasan hidup tenaga akademik akan terwujud,

Keenam, untuk mewujudkan dan meningkatkan kepuasan hidup baik dilihat dari kepuasan hidup finansial, kepuasan sosial dan kepuasan kinerja tenaga akademik, maka perlu adanya perhatian dan kebijakan yang konsisten dari pemegang kewenangan,

Jika pimpinan dapat mewujudkan keadaan dari ketiga kepuasan hidup tersebut kepada setiap tenaga akademik, maka tenaga akademik dapat melaksanakan semua Tri Dharma Perguruan tinggi yang menjadi tugas dan tanggungjawab mereka dan tidak harus dibebani kewajiban mencari tambahan untuk memenuhi kehidupan yang layak dan bermartabat,

Keterbatasan penelitian ini berkaitan dengan aspek pengaruh modal sosial, manfaat modal sosial, dan modal manusia terhadap kepuasan hidup tanaga akademik perguruan tinggi Negeri di Jawa Timur, sedangkan yang berkaitan dengan aspek lain tidak dalam pembahasan penelitian ini, Penelitian ini terbatas pada tenaga akademik perguruan tinggi negeri di Jawa Timur, Oleh karena itu, tidak dapat memberi gambaran umum atau digeneralisasikan sepenuhnya untuk tenaga akademik perguruan tinggi negeri diluar Jawa Timur atau tenaga akademik di seluruh Indonesia,

\section{DAFTAR PUSTAKA}

Amstrong, M. 2007. Human Resources Management Practice. Kogan Page. London. 
Baron, R. A. dan J. Greenberg. 1990. Behavior in Organizations: Understanding and Managing the Human Side of Work. Ed, ke-3. Allyn and Bacon. Boston.

Becker, G. S. 1993. Human Capital: A Theoritical and Empirical Analysis with Special Reference to Education. $3^{\text {rd }}$ ed. University of Chicago Press. Chicago.

Bock, J. 1982. Education and Development: A Conflict of Meaning. Comparative Education. Macmillan. New York.

Bontis, N. dan E. J. Fitz. 2002. Intelectual Capital ROI: A Causal Map of Human Capital Antecedents and Cosequents. Journal Intelectual Capital (online) 3(3): 223-247. http//www.emeraldinsigt.com Diakses 6 Nopember 2013.

Boxall, P. 1996. The Strategic HRM Debate and The Resources-Based View of The Firm. Human Resources Management Journal 6(3): 59-75.

Bretz, R. D. dan T. A Judge. 1992. The Relationship between Person Organization Fit and Career Success. Center for advanced Human Relation Studies. Cornell University. Working Paper 9: 211.

Bernardin, J. H. dan J. A. Russel. 1993. Human Resources Management: An Experiental Approach. MC Graw Hill. Singapore.

Chapman, D. W. dan S. M. Hutcheson. 1982. Teacher's Satisfaction with Teaching. Journal of Educational Research 75(4): 241247.

Chin, C. W. 2006. Pay Satisfaction. Job Satisfaction. Organizational Commitment. and Turnover Intention in Taiwan Banking: Structural Equation Modeling. Dissertation. Doctor of Philosophy. Lynn University.

Coleman, J. S. 1990. Foundations of Social Company. Harvard Business School Press. Cambridge.

Conley, S. C. S. B. Bacharach. dan S. Bauer. 1989. The School Work Environment and Teacher Career Dissatisfaction. Educational Administration Quarterly 25(1): 58-81.

Davis, J. A. 1993. Elementary Survey Analysis. Prentice-Hall Inc. New Jersey.
Fukuyama, F. 2000. The Great Depression: Human Nature and The Reconstitution of Social Order. Profile Book. London.

Gargiulo, M. dan Bernassi. 1999. The Dark Side of Social Capital. Corporate Sosial Capital and Liability. Boston.

Gattiker, U. E. dan L. Larwood. 1988. Predictors for Manajer's Career Mobility. Success and Satisfaction. Human Relations 41: 363-591.

Ghozali, I. 2008. Structural Equation Modeling. Universitas Diponegoro. Semarang.

Hackman, J. R. dan G. R. Oldman. 1976. Motivation through the Design of Work: Test of a Theory. Organizational Behavior and Human Performance 16: 250-279.

Hsu, M. K., H. G. Chen. J. J. Jiang. dan G. Klein. 2003. Career Satisfaction for Managerial and Technical Anchored IS Personnel in Later Career Stages. The Database for Advances in Information System 34(4): 64-72.

Kistyanto, A. 2008. Pengaruh Modal Sosial terhadap Kesuksesan Karier Manajer BUMN di Jawa Timur. Disertasi. Program Doktor. Fakultas Ekonomi Universitas Brawijaya. Malang.

Locke, E. A. 1976. The Nature and Cause of Job Satisfaction. Handbook of Industrial and Organizational Psychology. Rand Mac Nally. Chicago.

Marshall, R. 2005. Labor Standart. Human Capital. and Economic Development. Working Paper EPI (271).

Mayo, A. 2000. The Role of Employee Development in The Growth of Intellectual Capital. Personal Review (online) 29(4). http://www.emeraldlibrary.com. Diakses 19 Juni 2014.

Nawawi, H. 2003. Manajemen Sumber Daya Manusia. UGM Press. Yogyakarta.

Ongkorahardjo, M. 2008. Analisis Pengaruh Human Capital terhadap Kinerja Perusahaan (Studi Empiris pada Kantor Akuntan Publik di Indonesia). Journal Akuntansi dan Keuangan 10(1): 92-104.

Portal HR. edisi 51 juni 2008 (http/www. portail.cpm. Diakses 4 april 2010)

Rastogi, P. N. 2002. Sustaining Enterprise Competitiveness is Human Capital The 
Answer. Human System Management 19(3): 193-203.

Robbins, S. R. 2003. Organizational Behavior. 10th edition. Prentice-Hall Inc. New Jersey.

Schein, E. H. dan D. W. Kommers. 1972. Professional Education. McGraw Hill Book Company. New York.

Schermerhorn, J. R. 2002. Management. 7th edition. John Willey and Sons Inc. America.

Schultz, T. W. 1961. Investment in Human Capital. American Economic Review 51(1): 1-17.

Segall, G. B. dan S. Jerry. 2010. Founder Human Capital and Small Firm Performance: An Empirical Study Founder Managed Natural Food Stores. Journal of Management and Marketing Research 4(1): 1-10.
Seibert, S. E.. M. L.. Kraimer. dan R. C. Liden. 2001. A Social Capital Theory of Career Success. Academy of Management Journal 44: 219-237.

Sergiovani, T. J. 1987. The Principalship: A Reflective Pranctice Perpective. Allyn and Bacon. Boston.

Teixeira, A. 2002. On The Link Between Human Capital and Firm Performance. Working Paper (online) (FEP) Faculdade de Economia Universidade de Porto No. 121.

Undang Undang Republik Indonesia No. 20 tahun 2003. Tentang Sistem Pendidikan Nasional. Sekretaris Jendral Departemen Pedidikan Nasional.

.No. 14 tahun 2005. Tentang Guru dan Dosen. Sekretaris Jendral Departemen Pendidikan Nasional. 